\title{
Rotavirus Viral RNA Electrophoresis in Hospitalized Infants with Diarrhea in Santiago, Chile
}

\author{
LUIS F. AVENDAÑO, ${ }^{(12)}$ AQUILES CALDERÓN, JUAN MACAYA, INGEBOR PRENZEL AND \\ ELIANA DUARTE \\ Sección Virología, Depto. Microbiología y Parasitología and Depto. de Pediatría, Hospital Roberto del Río Facultad \\ de Medicina Santiago Norte, Universidad de Chile, Santiago, Chile
}

\begin{abstract}
Summary
Viral RNA electrophoresis technique was used to detect rotavirus in $\mathbf{2 2 6}$ children under 2 years of age with acute diarrhea, admitted to the Roberto del Río Hospital in Santiago, Chile, during the period of June 1979 through May 1980. A group of 50 children included in the aforementioned sample, admitted in winter, was compared with a control group of 25 infants without digestive pathology. In these groups, rotavirus was detected in 20 out of 50 children with diarrhea $(40 \%)$ but not in the controls $(0 \%)$ A positive diagnosis of rotavirus was found in 66 out of the total of 226 patients $(29.2 \%)$; its monthly distribution ranged between a maximum of $83.3 \%$ (June) and a minimum of $11.1 \%$ (October).
\end{abstract}

\section{Speculation}

The viral RNA electrophoresis technique for rotavirus diagnosis offers the advantage of simplicity and low cost, being specific and fairly sensitive. It can be very useful in the study of diarrheas, especially in developing countries. This technique can be implemented in any hospital laboratory.

Acute diarrhea in infants is one of the major health problems in developing countries $(9,10)$. In most cases the etiology is unknown. Previous studies have reported that enteropathogenic bacterias and parasites are found in $40-50 \%$ of the cases. In around $10 \%$ of the patients, viruses have been detected through classical techniques, such as serology and tissue culture $(2,11)$. Nevertheless, using other methods such as electron microscopy, it has been possible to associate rotavirus to diarrheic syndrome in $30-80 \%$ of the cases. Consequently, this viral group may well represent the most important single etiologic factor reported in the pathogenesis of acute infectious diarrhea $(1,6,7)$.

The high cost and complexity of the electron microscopy technique are factors that limit its application in the diagnosis of rotavirus to a very few laboratories. This situation has represented a challenge in the development of alternative diagnostic techniques (8). In 1978, Espejo et al. $(4,5)$ investigated acute diarrhea in Mexico City by comparing the results obtained in the detection of rotavirus by means of electron microscopy and electrophoresis of viral RNA. The latter method proved to be highly specific, of low cost, simple and roughly $80 \%$ sensitive. This new technique was applied in the present study in the detection of rotavirus in infants with acute diarrhea admitted to the Roberto del Rio Hospital in Santiago, Chile.

\section{MATERIALS AND METHODS}

During a 1 year period, from June 1979 to May 1980, 226 children were randomly selected from the overall admissions to the Roberto de Río Children's Hospital. The sample comprised
134 males and 92 females under 2 years of age, all of which presented an acute onset of severe diarrhea of less than 4 days duration. The incidence of enteropathogenic agents in the group of 50 cases admitted during winter (June through September, 1979) was compared with a control group of 25 infants showing no digestive pathology.

Two stool specimens were obtained from each patient within 48 $\mathrm{h}$ of admission. Rotavirus was investigated using the RNA electrophoresis technique previously described by Espejo et al. $(4,5)$. Briefly, the detection technique for rotavirus reads as follows: (1) suspension of 1-2 $\mathrm{g}$ of faeces in distilled water, (2) treatment with trifluorotrichloroethane, (3) centrifugation and recollection of the upper layer containing virus, (4) overnight precipitation of virus with polyethylene glycol, (5) centrifugation and resuspension of sediment containing virus, (6) disruption of virus with SDS-mercaptoethanol, (7) electrophoresis in agarose gels during $4 \mathrm{~h}$, (8) overnight staining of gels with ethidium bromide and (9) band reading with long wave ultraviolet light $(360 \mathrm{~nm})$. The faecal samples were either processed immediately or kept at $-70^{\circ} \mathrm{C}$ for days or wk; normally they were processed up to stage 5 a few days after recollection; thereafter the concentrated virus was kept frozen at $-20^{\circ} \mathrm{C}$ for days or months, before proceeding with the analysis. A vertical electrophoresis chamber with a capacity for 12 gels was used. A sample was deemed positive when at least the first four characteristic bands of the rotavirus, out of a total of nine, could be detected (4).

In both winter groups, diarrheas and controls, bacteriologic cultures were also performed using standard techniques for isolation. The identification was performed testing five colonies of $E$. coli from stool samples of each patient with recognized enteropathogenic types.

\section{RESULTS}

Rotavirus was detected in 20 out of 50 cases of diarrhea among the winter season group of children (40\%); no positive cases were found among the 25 control patients $(0 \%)$. The presence of enteropathogenic bacteria was proved in 26 out of 50 cases with diarrhea and in 13 out of the 25 control patients (Table 1). Enteropathogenic bacteria was isolated in 11 of 20 rotavirus positive cases $(55 \%)$. The $E$. coli serotypes identified were 026 , $044,086,0111,0124,0125,0126,0127$ and 0128 , which showed no predominance of a particular type.

The rotavirus survey during the 1 -year period in infants with diarrhea proved positive in 66 out of the 226 cases studied $(29.2 \%)$. The incidence of positive cases at different ages is shown in Table 2. The monthly distribution varied between $83.3 \%$ and $11.1 \%$ (Fig. 1). Among 56 rotavirus positive infants with diarrhea, all of them with two samples of faeces, $38(68 \%)$ were positive in both samples, $14(25 \%)$ were positive only in the first sample and $4(7 \%)$ had only the second sample positive. 
Table 1. Detection of rotavirus and enteropathogenic bacteria in infants hospitalized with acute diarrhea in Santiago, Chile (winter, 1979)

\begin{tabular}{lcc}
\hline \multicolumn{1}{c}{ Agent } & $\begin{array}{c}\text { Control }{ }^{1} \text { group } \\
(n=25)\end{array}$ & $\begin{array}{c}\text { Diarrhea group } \\
(n=50)\end{array}$ \\
\hline Rotavirus & $0(0 \%)$ & $20(40 \%)$ \\
E.P.E. coli & $13(52 \%)$ & $24(48 \%)$ \\
Salmonella & $1(4 \%)$ & $1(2 \%)$ \\
Shigella & $0(0 \%)$ & $1(2 \%)$ \\
\hline
\end{tabular}

${ }^{1}$ There was one case with both agents isolated (E. coli and Salmonella)

Table 2. Detection of rotavirus in infants hospitalized with acute diarrhea in Santiago, Chile (June 1979-May 1980). Age distribution

\begin{tabular}{ccc}
\hline Age (mo.) & Total & Rotavirus positive \\
\hline $0-2$ & 54 & $9(16.6 \%)$ \\
$3-5$ & 101 & $32(31.6 \%)$ \\
$6-8$ & 40 & $15(37.5 \%)$ \\
$9-11$ & 16 & $4(25.0 \%)$ \\
$12-23$ & 15 & $6(40.0 \%)$ \\
& & \\
Total & 226 & $66(29.2 \%)$ \\
\hline
\end{tabular}

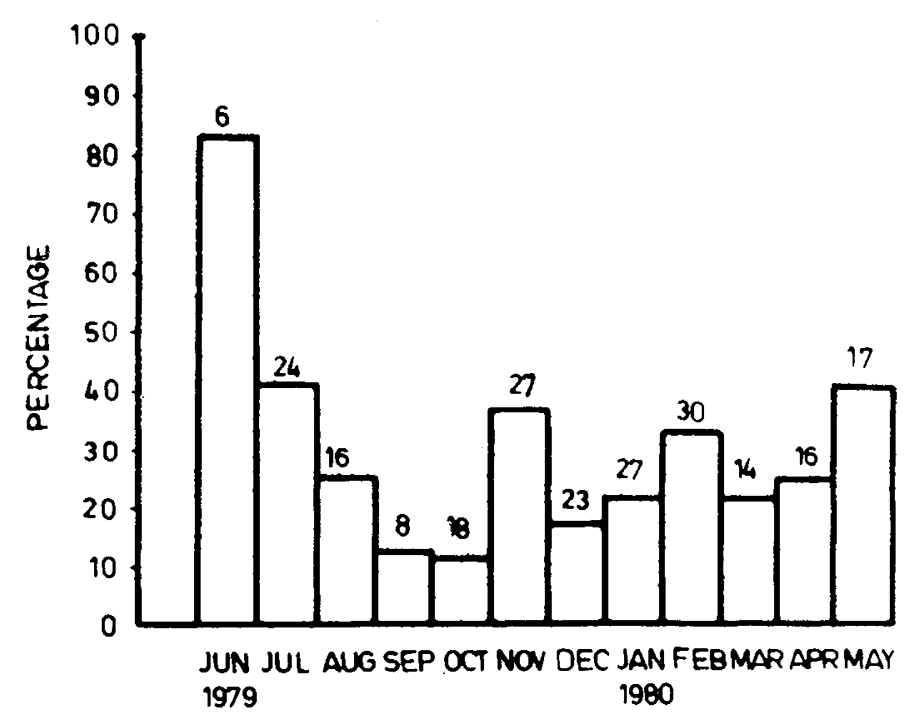

Fig. 1. Monthly \% distribution of rotavirus in infants hospitalized with acute diarrhea in June 1979-May 1980, Santiago, Chile. Total number of children studied each month is given.

\section{DISCUSSION}

The application of the viral RNA electrophoresis technique detected rotavirus in $40 \%$ of the children admitted with acute diarrhea during winter, showing negative results in the control group. This finding confirms the causal relationship between rotavirus and diarrhea. The isolation of enteropathogenic bacteria failed to prove a significant difference between both groups, a finding which is consistent with the current doubts about the enteropathogenicity of $E$. coli when it is evaluated exclusively through serotyping.

The viral RNA electrophoretic method is highly specific. The sensitivity is based upon the massive excretion of virus during the diarrheic episode of the amount of $10^{7}-10^{10}$ virus per $g$ of faeces (9). This method seems to be useful in detecting clinical infections. Subclinical infections and transient carriers probably do not excret enough virus to give a positive test. The negative findings of our control group, concur with previous reports (3) and they seem to confirm this assumption.

Our 12 month survey allowed us to detect rotavirus in $29.2 \%$ of the patients. These figures are very similar to those reported in previous studies using other technology, (8). The monthly distribution showed the highest virus positive rates in the cold months (June, July 1979) whereas the incidence in the other months was around $20 \%$ (Fig. 1). It seems interesting to point out that the rates of rotavirus found during the summer months, January and February, ranged between $22 \%$ and $33 \%$. Though these rates are not too high, the notorious seasonal increment of "summer diarrheas" represents a great absolute number of cases, emphasizing the role of rotavirus as a pathogenic agent in infantile diarrhea.

It also seems worthwhile to point out that if one considers the rotavirus positive cases, the analysis of the first faecal sample detected $93 \%$ of them, whereas the study of the second specimen increased the figure in $7 \%$. Therefore the analysis of more than two specimens will not increase significantly the sensitivity of the method.

Our results seem to reinforce the fact that the technique described by Espejo et al. is specific, simple, of low cost and fairly sensitive. Moreover, as it can be easily implemented in any clinical laboratory, it would be particularly useful for developing countries, where it would certainly contribute to the knowledge of human rotavirus infection.

\section{REFERENCES AND NOTES}

1. Bishop, R. F., Davidson, G. P., Holmes, I. H. and Ruck, B. J.: Evidences for viral gastroenteritis. N. Engl. J. Med., 289: 1096 (1973).

2. Cramblett, H. G., Azimi, P., and Haynes, R. E.: The etiology of infectious diarrhea in infancy, with special reference to enteropathogenic $E$. coli. Ann. N.Y. Acad. Sci., 176: 80 (1971).

3. Davidson, G. P., Bishop, R. F., Townley, R. R., and Holmes, I. H.: Importance of a new virus in acute sporadic enteritis in children. Lancet $1: 242$ (1975).

4. Espejo, R., Romero, P., Calderón, E., and González, N.: Diagnóstico de Rotavirus por electroforesis del RNA viral. Bol. Méd. Hosp. Infant. Méx., 35: 323 (1978).

5. Espejo, R., Calderón, E. and González, N.: Distinct Reovirus-like agents associated with Acute Infantil Gastroenteritis. J. Clin. Microbiol., 6: 502 (1977).

6. Flewtt, T. H., Bryden, A. S., and Davis, H.: Virus particles in gastroenteritis. Lancet, 2: 1497 (1973).

7. Kapikian, A. Z., Kim. A. W., Wyatt, R. G., Cline, W. L., Arrobio, J. O., Brandt, C. D., Rodriquez, W. J., Sack, D. A., Chanock, R. M., and Parrot, R. H.: Human Reovirus-like agent as a major pathogen associated with "winter" gastroenteritis in hospitalized infants and young children. N. Engl. J. Med., 294: 965 (1976).

8. Middleton, P.: Rotavirus: Clinical Observations and Diagnosis of Gastroenteritis. In: Kurstack, E. and Kurstack, C. Comparative Diagnosis of Viral Diseases pp. 423-445 (Academic Press, New York, NY 1977).

9. Soriano, H. and Macaya, J.: Síndrome Diarreico Agudo. In: J. Meneghello: Pediatría. Vol. 2, p. 1040 (Intermédica, B. Aires, 1978).

10. WHO Report. Scientific Working Group on Epidemiology and Etiology. Rotavirus and other viral diarrhoeas. Washington, D. C. 27-28 March 1979.

11. Wu, E., Grado, C. Avendaño, L. F., and Corey, G.: Etiología viral de la diarrhea infantil. Rev. Chil. Pediatr., 46: 119 (1975).

12. Requests for reprints should be addressed to: Dr. Luis F. Avendaño, Casilla 6673, Correo 7, Santiago, Chile.

13. This research was supported by Project M 876801 of Servicio de Desarrollo Científico, Artístico y de Cooperación Internacional. Universidad de Chile.

14. Received for publication December 2, 1980.

15. Accepted for publication August 5, 1981. 